\title{
A King Who Tames His Enemies and not who is Obedient to the Law ${ }^{1}$
}

\author{
Revo Arka Giri Soekatno
}

\begin{abstract}
AвSTRACT Dongeng tentang raja yang mengerti bahasa binatang terdapat versinya dalam Pañcatantra baik yang berbahasa Java Kuno maupun Pertengahan. Sadurannya juga terdapat dalam kesusasteraan Jawa Modern, seperti dalam siklus-siklus Anglingdarma. Namun, dalam berbagai versi Java ada kerancuan soal berbagai nama sang raja. Nama-nama tersebut misalnya Aridharma, Hari Dharma, Aji Dharma dan Angling Darma. Makalah ini akan membahas masalah nama raja ini dengan asumsi bahwa kejelasannya akan membantu perolehan pemahaman yang lebih baik tentang kesusastraan Jawa, baik Kuno maupun Modern.
\end{abstract}

Keywords Hari Dharma, Aji Dharma, Angling Darma, Arindama, haji, aji, angling, ari

The fable of a king who understands the language of the animals is a well known and a much loved fable of the various versions of the Pañcatantra. This story is also transmitted in the Old and Middle Javanese Pañcatantra renderings. There are adaptations of this fable in the Modern Javanese literature as well (i.e. the Angling Darma cycles).

In most versions the narration runs as follows: A king saw a dragon princess who was copulating with a lowly common snake. He could not stand this horrible sight of mixture of the castes (warnasangkara). Accordingly he killed the snake and hit the dragon princess. The dragon princess fled to the netherworld and told her father, the dragon king that a certain king abused her. Her father got angry and vowed to kill him. So he set off to his palace and hid himself in the royal bedchamber.

Meanwhile the king was resting with his consort. He looked terrible and the queen enquired him the reason. Consequently he told her about the incident. The dragon king who overheard the conversation realised that it was his own daughter who misbehaved. So he came out and asked to see the king. The king received him and got a boon, he now could comprehend the language of the animals, however on one condition: he was not allowed to share this knowledge to anyone else.

${ }^{1}$ The author wishes to thank Dr. Herman Tieken and Dr. Marijke Klokke from the University of Leiden who have helped the author into the writing of this paper by having provided him crucial information. The author also wishes to thank and Drs. H. Ong A Kwien, also from the University of Leiden who has given him several tips in the conception of this paper. 
Then the other day the king was making love with the queen again, while doing so he overheard the conversation of a pair of chichaks ('wall lizards') above them. He laughed and the queen was upset as she thought he made fun of her performance in bed. The king denied and told her about his newly acquired ability. So the queen would also like to have his ability as well. But the king refused and as a consequence the queen would rather die. As the king really loved her, he would also die as well to accompany her. But as they were ready to be burned at the funeral pyre the king overheard the conversation of a pair of goats. The female goat asked her mate to bring her some leaves from near the pyre, which were used as decorations. The male goat refused and she said she would rather die. The male goat just sneered at her and told her he was not like the king who listens to the words of his wife. Hearing this, the king was stunned; he descended from the cremation platform and returned to the palace. Meanwhile the queen and the female goat jumped into the fire.

In the Javanese versions there is some confusion about the name of the king. In the Tantri Kāmandaka edited by Hooykaas, he is known as king Aridharma while in other versions he is known as Hari Dharma, Aji Dharma and even as Angling Darma.

In this occasion, I wish to take a deeper look into this particular story and discuss the name of this king. This is important, as this will offer us a little contribution to a better understanding of not only the Old Javanese literature, but also of the Modern Javanese literature as well.

\section{Previous Researches}

The previous researchers who have made some detailed and important comment about the name of this king was Hooykaas (1929). Furthermore Drewes (1975) has made an extensive remark on Hooykaas' observation. Below I shall discuss Hooykaas' commentary and then after that Drewes' remark on Hooykaas.

Hooykaas was the first scholar who made a comment on the name of the king in the fable of a "King who understands the Language of the Animals". In his doctoral thesis, Hooykaas has said the following (1929: 27-28):

Aridharma heet de koning die de taal der dieren verstaat. Denken we hierbij aan sanskrit ari $=$ toegewijd, getrouw, ijverig, dan luidde zijn naam Koning Wetsgetrouw. Op Java waar ari = vijand in deze geen zin gaf - integendeel! - zal men gedacht hebben aan het epitheton hari (=ari) waaronder goden bekend waren, zooals Wişnu, Indra, enz. Goden stonden niet zoo ver van de koningen, zeker niet van een zoo gerechtig vorst als Haridharma, die ook Koning Wet $=$ Hajidharma ging heeten . Daar aji de beteekenis heeft van wetboek, tooverformule, heilige schrift, en in de spelling wel niet consequent onderscheiden zal geweest zijn van haji, zal de lezing en interpretatie Ajidharma wellicht den weg gebaand hebben voor latere angling (=zeggen, meenen, betekeenen) in den naam Angling Dharma.

'Aridharma is the name of the king who understands the language of the animals. If we should think of the Sanskrit ari 'devoted, obedient, diligent', then his name means King Obedient to the Law. In Java where the name ari 'enemy', does not mean anything, on the 
contrary! - one must have thought of the epithet hari (=ari) to which the gods were known such as Wişnu, Indra, etc. Gods were not far form the kings, especially not from such a righteous king as Haridharma who has become known as King Law (=Hajidharma). As aji has the meaning of 'law book, magic formula', Holy Scripture and in spelling not it is not consequently distinct from haji, the reading of this would have paved the way for the later angling ('to say, to suggest, to mean')'

Here Hooykaas suggests that angling ('to say, mean, signify') in the name Angling Darma is a newer substitution for the older aji ('lawbook, magical formula; holy scripture'); and that actually aji should be read as haji ('ruler, king'), as king Aridharma who occurs in the Tantri Kāmandaka is also called Haji Dharma. According to Hooykaas the Skr. Word aridharma means 'obedient to the law'. However, in Java only the Sanskrit word ari which means enemy, exists, and this meaning is not relevant here, on the contrary! The synonym Haji Dharma may thus have derived from ari via the following progression: ari $=$ Hari $=$ Wişnu $=$ king according to the Old Javanese concept of kingship $=$ haji, and then changed via haji $>$ aji $>$ angling to Angling Dharma ${ }^{2}$.

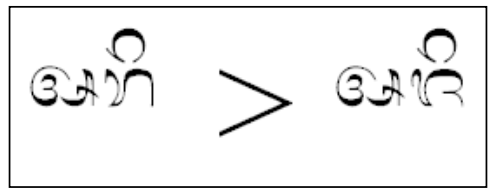

Plate 1. A Graphical Depiction of the Possible Change from ari-aji.

Drewes further thinks that this complicated explanation is rather farfetched. He thinks that it is unlikely that the well-known word haji, still widely used at present, should have been confused with the equally well-known word aji ('magical formula, etc.') in a proper name. And secondly, aji ('magical formula') has not the same meaning as angling ('to say').

Then Drewes discuss his own solution to this problem, however his solution is not relevant although I have to say that I agree with Drewes' remark on Hooykaas.

\section{My Solution}

After having discussed both the explanation of Hooykaas and Drewes' remark, I would like to propose an alternative solution to this name below. I hold the view that the name 'Aridharma', Hooykaas and Drewes to which they based upon their judgment is corrupted. This name is indeed handed down in all the manuscripts Hooykaas has been using in bringing us his text edition in 1931 and in any other Balinese manuscripts containing Tantri Kāmandaka I have ever seen, including the famous Jadi-manuscript which the Dutch scholar Hedi Hinzler has found as evidenced in Marijke Klokke's dissertation (1993: 25) and which is now kept as codex Or 18.673 in the Leiden University Library. For his critical edition of the Tantri Kāmandaka, Hooykaas used the Leiden

\footnotetext{
$2 \quad$ Based Drewes (1975: 20).
} 
manuscripts codex Or 4.533 and 4.534 .

I have found another name, which does make sense and does not need any complicated reasoning. The name I have found is Arindama. I have found this name in a London manuscript (British Library IOL 53 a), which is a manuscript of Javanese provenance. A diplomatic transliteration of the relevant section in the manuscript is provided in appendix 2 . This name is a better name than Aridharma as it is immediately comprehensible. Arindama is a tatpuruşa construction in Sanskrit and it literally means 'subduer of the enemies' or 'tamer of the enemies'. This name, which is in good Sanskrit, is a common name for kings in ancient India. This is especially true, as I have identified several Indian kings who bore this name. These names are included in appendix 1.

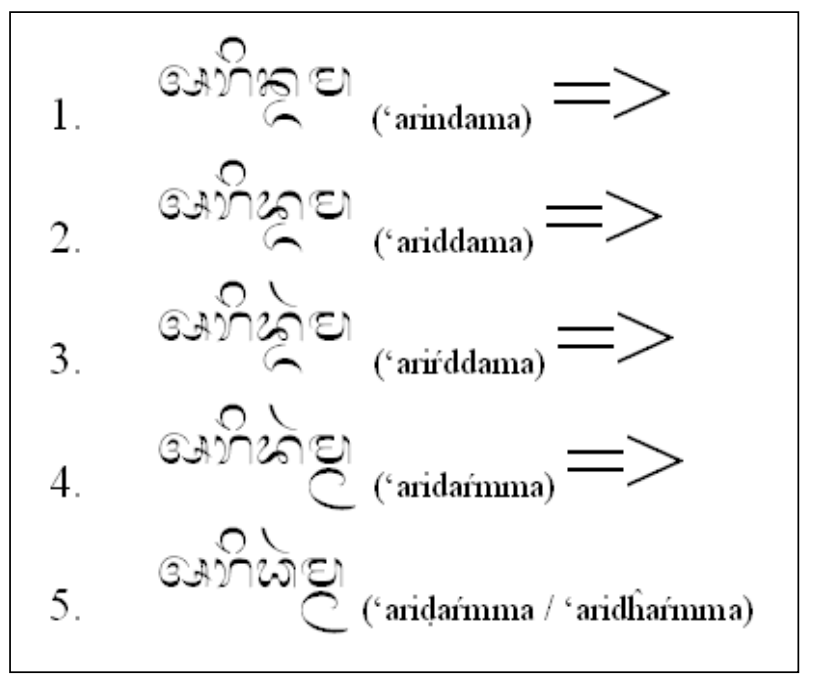

Plate 2. The transformation from Arindama to Aridharma in Hanacaraka script. Here the modern Javano-Balinese typeface has been taken as an example.

The next question will then be how the name Arindama is transformed to Aridharma. The explanation involves a palaeographical analysis. In some variants of the Hanacaraka script, the letter $\mathrm{n}$ resembles a $\mathrm{d}$. So some time in the past, a copyist must have made an error for substituting an $\mathrm{n}$ with a $\mathrm{d}$, as both look similar. Then the name Arindama is changed to Ariddama. Another copyist who saw this name and did not understand the text must have added a pre-consonantal $r$ (a surang in Balinese or a layar in Javanese), as a double consonant usually requires an $r$ before the doubling takes place. After that the place of the $r$ and the doubling of the consonants are moved to the right as ddama might have looked odd and darmma was more acceptable. In fact the copyist might have associated this with the more familiar dharmma. At last the transformation from Arindama to Aridharma is completed.

A caveat must be inserted here however. This change from $n=>$ could only have taken place in the Balinese variant or the Eastern Javanese variant of 
the Hanacaraka script. In modern Central Javanese variant of the Hanacaraka script, the ductus of the $\mathrm{n}$ does not resemble the $\mathrm{d}$ anymore.

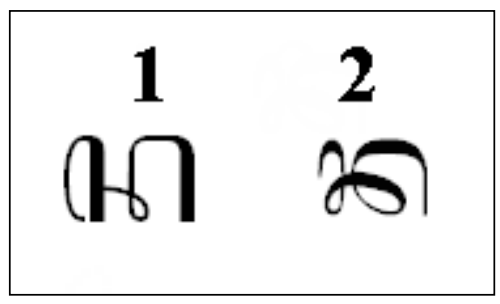

Plate 3. The letter ' $n$ ' in the modern Central Javanese variant (1) and the Balinese variant (2) of the Hanacaraka script.

\section{TANTROPĀKHYĀNA}

As an aside I would also like to discuss the finding of George Artola (1957) and consequently also Marijke Klokke's assumption (1993:37) that a certain Indian work called the Tantropākhyāna (published by Śāstrī (1938)) might have been the Indian source for the Old Javanese Tantri Kāmandaka.

However, in this work, the Tantropākhyāna, which also contains the fable "The King who Understands the Language of the Animals", the name of the king is spelled differently. The name of the protagonist of this fable is 'Anaranya' ${ }^{3}$. According to Dowson $(1993, \mathrm{sv})$ Anaranya is a "descendant of Ikshvaku and king of Ayodhya". It is however not known whether Arindama is also another name or an epithet of him.

\section{Conclusion}

In the Javanese versions of the Indian Pañcatantra, for example the Old Javanese Tantri Kāmandaka, the name of the protagonist in the fable of the "King who understands the language of the animals" is usually handed down as Aridharma or Aji Dharma. This name has led to more modern names such as Angling Darma. However the name Aridharma is a corruption, as it does not make sense. On the other hand, the author of this paper has showed that there might be another name, which might be better for the protagonist of this story. This name is Arindama and it is found in the only Javanese manuscript found which contains the Old Javanese prose work Tantri Kāmandaka.

\section{REFERENCES}

Manuscripts:

British Library London: IOL 53 a, Tantri Kāmandaka

Leiden University Library: L Or 18.673, Tantri Kāmandaka

Published works:

Artola, George (1957), 'Pañcatantra manuscripts from South India', The Adyar Library Bulletin 21:185-262.

\footnotetext{
${ }^{3}$ This information was kindly provided by Marijke Klokke.
} 
Dowson, J. (1993), Classical Dictionary of Hindu Mythology. New Delhi: Heritage Series. Drewes, G. W. J., 1975, The Romance of King Angling Darma. The Hague: Martinus Nijhoff. Hooykaas, H.C., 1929, Tantri, De Middel-Javaansche Pañcatantra Bewerking. Leiden: A.Vros. [Unpublished doctoral thesis].

(1931), Tantri Kāmandaka. Bandoeng: Nix. Bibliotheca Javanica 2.

Klokke, Marijke J.,1993, The Tantri Reliefs on Ancient Javanese Candi. Leiden: KITLV Press. Verhandelingen van het Koninklijk Instituut voor Taal-, Land- en Volkenkunde 153.

Sastri, K. Sambasiva (1928), 1938, The Tantropākhyāna. Trivandrum: Government Press. [Trivandrum Sanskrit Series 132].

\section{ApPendix 1}

A list of several ancient Indian kings who bore the name "Arindama". Retrieved from the website: http://www.palikanon.com/english/pali_names/ay/arindama.htm on Saturday July 9, 2005:

1. Arindama.-The Bodhisatta, born as King of Benares and son of the Magadha King of Rájagaha. During the time of Sikhí Buddha he held a great almsgiving for the Buddha and his monks; he presented to the Order a fully caparisoned elephant which he redeemed by giving suitable gifts to the height of an elephant (J.i.41; Bu.xxi.9). He had as friend the chaplain's son, Sonaka. They both studied in Takkasila and at the conclusion of their studies they travelled about in search of experience. In the course of their travels Arindama was elected to succeed the King of Benares who had died childless, and Sonaka became a Pacceka Buddha. Forty years later Arindama wished to see Sonaka, but no one could tell him his whereabouts in spite of the offer of a large reward. Ten years later Sonaka saw the king through the good offices of a lad of seven, who belonged to the harem and had learnt a song composed by the king expressing his desire to meet Sonaka. At the meeting, however, the king failed to recognise him. Sonaka, not revealing his identity, spoke to the king about the joys of renunciation, and disappeared through the air. The king, moved by his words, decided to give up the throne and to follow the ascetic life. He appointed his eldest son Díghávu king in his stead, handed over to him all his possessions, and developing supernatural faculties was born in the Brahma world (J.v.247-61).

Arindama is mentioned together with Mahájanaka as an example of a king who renounced a mighty kingdom to lead a hermit's life (J.iii.489). The story also appears in the Mahávastu (iii.449ff), but the details given differ from those of the Jataka version. There Arindama is spoken of as the King of Mithilá.

In both accounts Díghávu's mother, the king's chief queen, is spoken of as having died before the king's renunciation.

According to the Buddhavamsa Commentary (BuA.203), Arindama's capital was Paribhuttanagara. (v.l. Arindamaka.)

2. Arindama.-King in the time of Sumana Buddha. A great dispute had arisen at this time regarding nirodha and all the inhabitants of many thousand world systems were divided into two camps. In order to settle their doubts, the disputants, with Arindama at their head, sought the Buddha. The Buddha sat on Mount Yugandhara while Arindama, with his ninety thousand crores of followers, sat on a golden rock, which by the power of his merit had sprung from the earth near Sankassa. The Buddha preached to them, and at the end of the sermon they all became arahants. BuA.128-9.

3. Arindama.-King of Uttara. When Revata Buddha visited his city the king went to see him, accompanied by three crores of people. The next day a great almsgiving was held for the Buddha and the monks, and also a festival of light covering a space of three leagues. The Buddha preached to the assembly, and one thousand crores of people realised the Truth. Bu.vi.4; BuA.133.

4. Arindama.-A king of forty-one kappas ago; a former birth of Sannidhápaka Thera. Ap.i.97.

5. Arindama.-King of Hamsavatí. When the king, through carelessness, had lost his wealth, his setthi (Jatukannika in a former birth) made good the loss by giving him the seven kinds 
of jewels. Ap.ii.360.

6. Arindama.-The name given to the Cakkavatti's cakkaratana because it brings all his enemies into subjection. Mbv.72.

\section{Appendix 2}

A diplomatic transliteration of the fable: "The king who understands the language of the animals" according to the London manuscript IOL 53 a.

98 b ? recto:

1. ... ${ }^{4}$ puguti ; kerid tikań wre ; ma... ${ }^{5}$ unta wakti ; nahan śakti halah $\square$ denij upaya ; matańnyan sijĕmpwan. yātna ki hinaśakti ; mankana doniń si sambadd $\square \bar{a}$; madyum ya ri sań ca

2. $\quad . . .{ }^{6}$ non sań bĥasubaga magawe śloka + 'akṛtan ta wikam $\square$; kaŕmmalah $\square$ yajňā dbĥawet. pūíwwa nibitam $\square$; pan $\square \mathrm{d} \square$ ite dewata napih $\square+$ ' 'artthanya ; 'ikay anugrahāni dewata ; tan. wnań hinilāgan.; mań

3. $\quad . .{ }^{\urcorner} \mathrm{n} \square \mathrm{d} \square$ ita; mojaŕtta sań sambadd $\square \bar{a}$; lińnya; kahid $\square$ ĕp ta wuwusninhulun.; sań can $\square \mathrm{d} \square$ a pingala; ndā yogya hid $\square$ ěpěn pitutur ińsun. ; kadi hanganikań wd $\square$ us. ; pinintuhu denikań ratu harindama ; su

4. $\quad . . .{ }^{8} \mathrm{n} \square \mathrm{d} \square$ a pingala ; 'apa wuwusnikań wd $\square$ us. ; yan pinintuhu de sań ratu ; sumahứr ikań sambadd $\square \bar{a}$; hana sira sań prabĥ̄ harindama ; ya ; sira lumakw abĥuru bĥurū ; 'amangih $\square$ ta sira nāgan $\square$ a nagin $\square \mathrm{i}$ ; halaki hu

99 a ? verso:

1. ... ${ }^{9}$ wāŕn $\square$ na sayśara hid $\square$ ĕpira; kadi brahmān $\square$ i halaki sudra; rajaputri halāwan sudra; mạkana tekań nagin $\square \mathrm{i}$; palaki hula dlěs. yogya $\mathrm{d} \square$ uměn $\square \mathrm{d} \square$ aha ; 'ann annira mankana ; pinatyanira hu

2. $\quad . .{ }^{10}$ kań nāgin $\square \overline{1}$ pinalunira juga ; mulih $\square$ ta ya mareń pātala ; tka nanis ta warah $\square$ ri sań bapa ; yan marāja harindama malū ; 'ala [wa] tan lanawanan. ; krodd $\square$ a ta sań bapa manhid $\square$ ěp awarah $\square$ hin ana

3. ... ${ }^{11}$ sań bapa ; haywa sayśaya naku ; tumama tayeń kad $\square$ atwan. ; sumapawaknā brahmān $\square \mathrm{a} ; \mathrm{d} \square$ atań te yen umah $\square$ sań ratū ; muwah atmahan nāga sumurup i sớniń phalankā ; sań ratu haturwan turwan. lāwan ta

4. ... ${ }^{12}$ jari strinira ; sajňā haji hapa yekaniń hań... ${ }^{13} \mathrm{n}$ kady ann annön. ; hana wastwa tinonku rin alas. ; nagin $\square$ i halaki hula dlěs. ; waŕn $\square$ nasayśara hid $\square$ pinhulun. ; dak patyani kay ula dlěs. ; ‘i

99 b ? recto:

1. $\quad . .{ }^{14}$ dak anĕnn aněn. ; liń sań prabĥu maykana ; mara ri strīnya ; 'ařyö nāga hi soŕniń pĥalajkā ; suka manah $\square$ nya 'akodiwya

2. $\quad . .{ }^{15}$ naku ya; dứŕsila; 'irika sata.. ${ }^{16}$ mbesuk tumama tekańnāga muwah $\square$ riń kad $\square$ atwan.; sań brahmān $\square \mathrm{a}$ rūpa ; mojaŕnikań nāga ; sajňā haji ; hantyanta wawařyön sań pra

3. $\quad . .{ }^{17}$ panińnāgin $\square \mathrm{i}$;tinmuntāparitus $\square$ ţamanah $\square$ mamihaji; $\square$ uměn $\square \mathrm{d} \square$ asalah $\square$ śila;matańnyanparanke ; dak anugrahani ; sumahứ sań ratu ; 'ahyun. halun. wruha śabdani

4. $\quad . .{ }^{18}$ warah $\square$ rińlen.; yanmawarah $\square$ rińlenmatikita; mulih $\square$ tayeńphhala; sań prabĥūnmu sunyāmběknya

\footnotetext{
${ }^{4}$ ms. damaged.

${ }^{5} \mathrm{~ms}$. damaged.

${ }^{6} \mathrm{~ms}$. damaged.

${ }^{7}$ ms. damaged.

${ }^{8} \mathrm{~ms}$. damaged.

${ }^{9} \mathrm{~ms}$. damaged.

${ }^{10} \mathrm{~ms}$. damaged.

${ }^{11} \mathrm{~ms}$. damaged.

${ }^{12} \mathrm{~ms}$. damaged.

${ }^{13} \mathrm{~ms}$. damaged.

${ }^{14} \mathrm{~ms}$. damaged.

${ }^{15} \mathrm{~ms}$. damaged.

${ }^{16} \mathrm{~ms}$. damaged.

${ }^{17} \mathrm{~ms}$. damaged.

${ }^{18} \mathrm{~ms}$. damaged.
} 
; ka ; lara hina ; 'aturu sań prabĥ̄ mwań strinya ; 'ana' ${ }^{19} \ldots$

100 a ? verso:

1. ... ${ }^{20}$ kinya ; lińnya ; rāma sań wilāśa pati ; mon si mahārāja ; 'akule rahina wni ; tan maykana hulahanta denta syami ; mankana lińnikań cěcěk. ; ri lakinya 'ařyö ${ }^{21}$

2. ... ${ }^{22}$ linaniń guyū parameśwara ; warahana kalińnanen guyu ; 'adwa haji warahěn. ywań ; 'adwa masih $\square$ sań prabĥu ; katuhwan. yan mankana ; pakwan agawe tulanan. ; para $\tan \square \mathrm{d} \square \overline{\mathrm{a}}$

3. $\quad . .{ }^{23} \mathrm{ha}$; hiri kita..${ }^{24} \mathrm{n} \square \mathrm{a}$ we tań tuno... ${ }^{25}$ spa ri pūŕn $\square$ na ; winawaran salwiŕnya ; mawe ta sira dĥāna ri sań brahmān $\square \mathrm{a}$; śewa śogata ; maheśwara tlas apuyunta riń ${ }^{26} \mathrm{ma}$

4. $\quad . .{ }^{27} \mathrm{nd} \square \mathrm{y}$ anantara hana tastiniń wd $\square$ us. ; si wipali yaranira ; yaraniń lakinya swastĥa ; ya ; strīnya malaku wawāíyya nidam. ;

$100 \mathrm{~b}$ ? recto:

1. ....sah $\square$ saba... ${ }^{28}$ paknā kuwawārniń tunyan. ; ‘e naga naganyāmběkku ; sumahứr ikań lakinya ; ‘awdi ya ku waneh $\square$ waneh $\square$ patwana mwań la... ${ }^{29}$

2. $\quad . .{ }^{30}$; nya ; katuhwan. ; yan mankana ; yan tan masih $\square$ kiteń yry aku ; sakayanya göń hyunku rikiń wawar. ; tan kawnań denya mati lińnya ; sumahuŕ lakinya sala... ${ }^{31}$

3. $\quad . .{ }^{32}$ ma ; makamatya denin anakbi ; 'awdi wadwan ta dĥấrmmani lanań ; dūŕyyas $\square$ a satriya ; mulat māhāja harindama ; ruměnö śābdanikań wd $\square$ us. ; 'uda.i... ${ }^{33}$

4. $\quad . .34$ jariń wadwan.; 'aku hari pan manus $\square$ a towin prabĥū haku ; yan satwā matan pamintuhu śojari strinya ; mankana ... ${ }^{35}$

101 a ? verso:

1. $\quad . .{ }^{36}$ śābdaniń wd $\square$ us. ; langěń sira siniwi riń sinhańśan $\square \mathrm{a}$; nahan tinon sań $\mathrm{d} \square$ ań hyań bhasubĥaga magawe śloka + 'u[..]ma... ${ }^{37}$

2. $\quad . .{ }^{38}$ dyottama ; yogya wawařyöhön sahala hayuniń wuwusnya ; nahan. wiwi nintuhū de sań ratu ; harindamma ; hujaŕnya ; [...]

\footnotetext{
${ }^{19} \mathrm{~ms}$. damaged.

${ }^{20} \mathrm{~ms}$. damaged.

${ }^{21} \mathrm{~ms}$. damaged.

${ }^{22} \mathrm{~ms}$. damaged.

${ }^{23} \mathrm{~ms}$. damaged.

${ }^{24} \mathrm{~ms}$. damaged.

${ }^{25} \mathrm{~ms}$. damaged.

${ }^{26} \mathrm{~ms}$. damaged.

${ }^{27} \mathrm{~ms}$. damaged.

${ }^{28} \mathrm{~ms}$. damaged.

${ }^{29} \mathrm{~ms}$. damaged.

${ }^{30} \mathrm{~ms}$. damaged.

${ }^{31} \mathrm{~ms}$. damaged.

${ }^{32} \mathrm{~ms}$. damaged.

${ }^{33} \mathrm{~ms}$. damaged.

${ }^{34} \mathrm{~ms}$. damaged.

${ }^{35} \mathrm{~ms}$. damaged.

${ }^{36} \mathrm{~ms}$. damaged.

${ }^{37} \mathrm{~ms}$. damaged.

${ }^{38} \mathrm{~ms}$. damaged.
} 